\title{
TRANSAMINASE ACTIVITY IN HUMAN BLOOD
}

\author{
By ARTHUR KARMEN, FELIX WRÓBLEWSKI, AND JOHN S. LADUE \\ (From the Sloan-Kettering Institute, Department of Medicine, Memorial Center, \\ New York City, N. Y.)
}

(Submitted for publication April 3, 1954 ; accepted July 15, 1954)

Enzymatic transamination consists of the enzyme catalyzed reversible transfer of the alpha amino nitrogen of an amino acid to an alpha-keto acid with the synthesis of a second amino acid and a second alpha-keto acid. Enzymes catalyzing different transamination reactions are found widely distributed in animal tissues and have been shown to change in activity in some tissues during disease (1-3). These observations prompted the present study to determine if transaminase activity could be demonstrated in human serum and blood cellular elements and, if so, to study any variations in activity of this enzyme in the blood of normal and diseased man.

\section{METHODS AND MATERIALS}

The two transaminases found most active in animal tissues are:

1. "Glutamic-oxalacetic transaminase"

Aspartate + alpha-keto glutarate $\rightleftharpoons$ glutamate + oxalacetate

2. "Glutamic-pyruvic transaminase"

Alanine + alpha-keto glutarate $\rightleftharpoons$ glutamate + pyruvate

When aspartate or alanine are incubated with alphaketo glutarate and a source of enzyme, the rate of production of glutamate may be taken as a measure of transaminase activity. The amount of glutamate produced after a given incubation period under standardized conditions was measured by quantitative paper chromatographic analysis (4).

One-tenth molar solutions of 1-aspartate, 1-alanine, and alpha-keto glutarate were prepared in $0.06 \mathrm{M}$ phosphate buffer and the $\mathrm{pH}$ of the solutions adjusted to $\mathrm{pH}$ 7.6. For serum transaminase determinations, $0.5 \mathrm{ml}$. of clear, non-hemolyzed serum, $1.5 \mathrm{ml}$. of $0.06 \mathrm{M}$ phosphate buf-

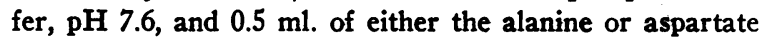
solutions were incubated for ten minutes at $37^{\circ} \mathrm{C}$. At this time, $0.5 \mathrm{ml}$. of the alpha-keto glutarate solution was added and the incubation continued for 18 hours. For whole blood hemolysate transaminase determinations, equal volumes of blood and distilled water were shaken together for ten minutes, $1.0 \mathrm{ml}$. of the hemolysate was added to $1.0 \mathrm{ml}$. of the phosphate buffer, and the substrates added as above. The time of incubation of the hemolysate substrate mixture was three hours.
At the end of the incubation period, proteins were separated by adding $7.0 \mathrm{ml}$. of absolute ethyl alcohol, centrifuging for ten minutes, and washing the precipitate with $5 \mathrm{ml}$. of 70 per cent ethanol. The supernatant was evaporated to dryness over a water bath and the residue dissolved in $1.0 \mathrm{ml}$. of $0.06 \mathrm{M}$ phosphate buffer. Aliquots of $0.05 \mathrm{ml}$. were then applied to Whatman No. 1 filter paper and chromatographed by the descending method for 18 hours, using phenol saturated with water as solvent and water saturated with phenol to saturate the atmosphere of the tank. The papers were then removed and dried in air at room temperature (5). The position of the amino acids was located by spraying the paper with a 0.1 per cent solution of ninhydrin in butanol and heating gently with an infra-red lamp.

The areas of paper corresponding to glutamate were cut out, rolled, and placed in test tubes. Elution of the amino acid from the paper and quantitative color development with ninhydrin were performed in one operation by adding the reagents and treating the paper as described in the procedure of Troll and Cannan (6). Areas of paper containing standard amounts of glutamate were analyzed concomitantly. Papers corresponding to incubation mixtures containing $0.5 \mathrm{ml}$. of serum, or $1.0 \mathrm{ml}$. of hemolysate were used as blanks.

\section{RESULTS}

\section{Reliability of the method}

No loss of glutamate was encountered in the incubation period with serum or in the process of paper chromatography. Satisfactory recovery of known quantities of glutamate added to serum and incubated for 18 hours, or applied to paper directly, was obtained (Table I).

\section{Presence and properties of the enzyme in serum}

Incubation of aspartate and alpha-keto glutarate or alanine and alpha-keto glutarate, without addition of serum, failed to form detectable quantities of glutamate after 18 hours of incubation. Incubation of $0.5 \mathrm{ml}$. of serum and any one of the substrates singly, similarly showed no formation of measurable glutamate. Thus, non-enzymatic transamination was inferred not to occur under the conditions of these experiments, and concen- 
TABLE I

Recovery of added glutamate

\begin{tabular}{lccc}
\hline \hline Mliquot & $\begin{array}{c}\text { Micromoles } \\
\text { added }\end{array}$ & $\begin{array}{c}\text { Micromoles } \\
\text { recovered }\end{array}$ & $\begin{array}{c}\% \\
\text { Recovery }\end{array}$ \\
\hline
\end{tabular}

A. From paper after phenol chromatography

\begin{tabular}{llll}
\hline 1. & 0.405 & 0.410 & 101.1 \\
2. & 0.405 & 0.405 & 100.0 \\
3. & 0.405 & 0.415 & 102.3 \\
4. & 0.405 & 0.424 & 104.7 \\
\hline
\end{tabular}

B. From serum after eighteen-hour incubation

\begin{tabular}{lrrr}
\hline 1. & 8.00 & 8.10 & 101.1 \\
2. & 8.00 & 8.57 & 107.0 \\
3. & 8.00 & 7.60 & 95.0 \\
\hline
\end{tabular}

tration of alpha-keto glutarate and amino group donors in serum and hemolysates was inferred to be negligible. Incubation of $0.5 \mathrm{ml}$. of serum with aspartate and alpha-keto glutarate resulted in the formation of from 4.4 to 15.0 micromoles of glutamate in 18 hours, depending on the serum sample tested.

The amount of glutamate produced was found to be directly proportional to the time of incubation when identical mixtures of serum, buffer, and substrates were incubated for varied intervals of time (Figures 1 and 2). The rate of production of

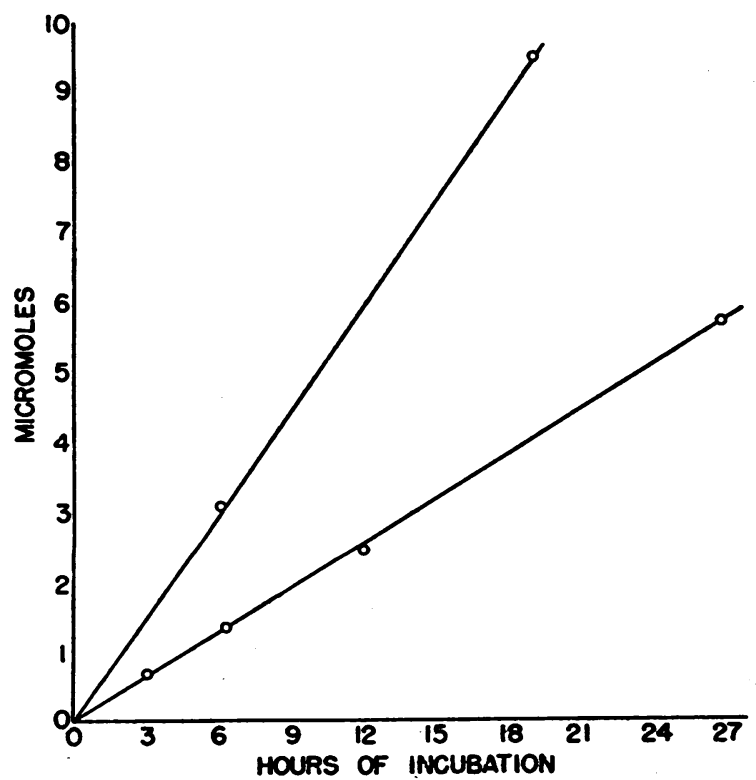

Fig. 1. Tmme Rate of Glutamate Production Via Transamination (Two 0.5 ML. Serum Samples)

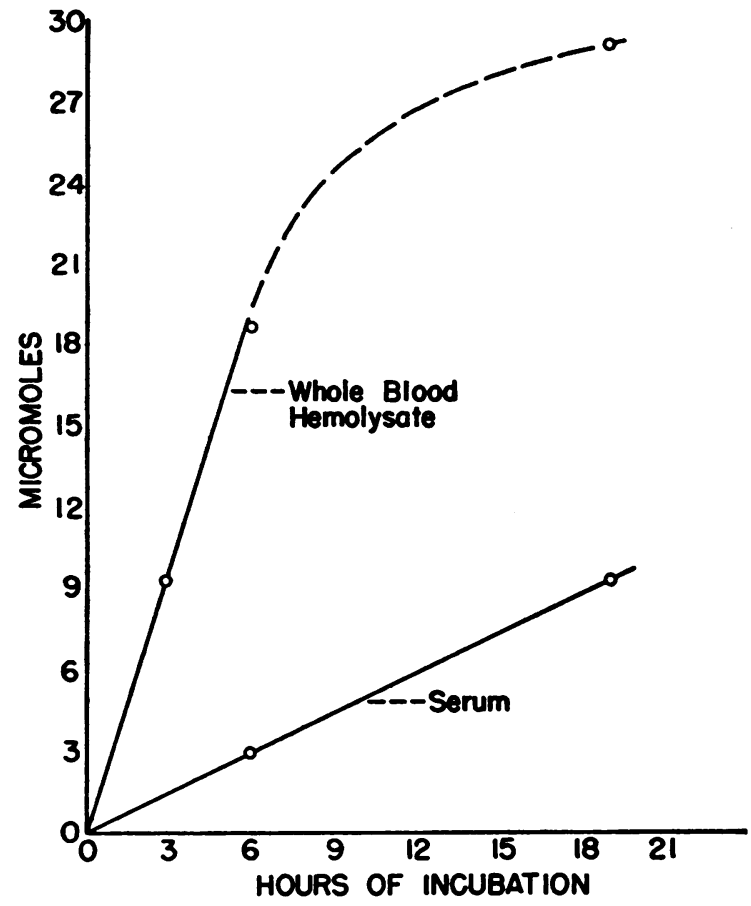

Fig. 2. Rate of Glutamate Production Via Transamination (Wholr Blood Hemolysate and Stros Compared)

glutamate was seen to be directly proportional to the quantity of serum, when $0.5 \mathrm{ml}$. and $1.0 \mathrm{ml}$. samples of the same sera were incubated with identical substrate mixtures (Table II).

Pyridoxal phosphate has been shown to act as coenzyme in transamination reactions and O'Kane and Gunsalus have determined the coenzyme saturated curve (7). Addition of a buffered solution of pyridoxal phosphate in a concentration of ten micrograms per $\mathrm{ml}$. was found to have no measurable effect on the transaminase activity of the serum. Addition of a boiled and filtered extract of rat liver, used as source of possible activators,

TABLE II

The effect of enzyme concentration on rate of transamination incubation period-twenty hours

\begin{tabular}{ccccc}
\hline \hline & $\begin{array}{c}\text { Micromoles } \\
\text { glutamate } \\
\text { produced } \\
\text { by 0.5 ml. }\end{array}$ & $\begin{array}{c}\text { Rate } \\
\text { micromos/ } \\
\text { ml./hr. }\end{array}$ & $\begin{array}{c}\text { Micromoles } \\
\text { glutamate } \\
\text { produced } \\
\text { by 1.0 ml. }\end{array}$ & $\begin{array}{c}\text { Rate } \\
\text { micromoles/ } \\
\text { ml./hr. }\end{array}$ \\
\hline Sample & -5.6 & 0.56 & 10.4 & 0.52 \\
2. & 5.9 & 0.49 & 9.7 & 0.48 \\
3. & 6.6 & 0.66 & 11.0 & 0.55 \\
4. & 6.4 & 0.64 & 11.7 & 0.59 \\
5. & 5.9 & 0.59 & 12.3 & 0.61 \\
6. & 5.2 & 0.52 & 9.8 & 0.49 \\
\hline
\end{tabular}


was similarly found not to affect the observed transaminase activity of serum.

Increased concentration of aspartate in a given serum incubation mixture was seen to cause a greater increase in the observed rate of glutamate production than an increase in the concentration of alpha-keto glutarate, demonstrating that complete saturation of the enzyme with substrate had not been achieved at these concentrations. These results are in essential agreement with those reported for transaminase preparations from pig heart muscle $(7,8)$.

The effect of $\mathrm{pH}$ on serum transaminase activity was studied by altering the composition of the buffer used. Phosphate buffer, $0.2 \mathrm{M}$, of several $\mathrm{pH}$ values was substituted for the $0.06 \mathrm{M}$ buffer. The $\mathrm{pH}$ of each incubation mixture was determined before and after incubation. An increase in $\mathrm{pH}$ from 0.1 to $0.2 \mathrm{pH}$ units was observed in each sample after the incubation period and the average of the pre- and post-incubation values was taken as the $\mathrm{pH}$ of the mixture. The finding of maximal activity between $\mathrm{pH} 7.0$ and 8.0 (Figure 3 ) is in essential agreement with the results of Cohen (9) and others using pig heart muscle as source of transaminase.

No change in transaminase activity with time was noted in serum samples stored from ten minutes to 96 hours at room temperature, or for periods of from one hour to two weeks in the refrigerator $\left(0\right.$ to $5^{\circ} \mathrm{C}$.). The transaminase activity was not changed by freezing or lyophilization of

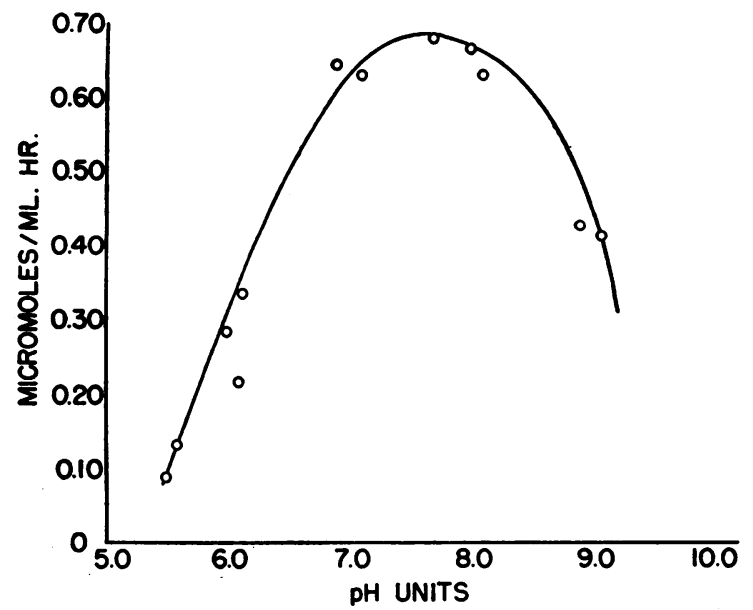

Fig. 3. Effect of Varying Hydrogen Ion Concentrations on Serum Transaminase Activity
TABLE III

Distribution of transaminase activity in serum of healthy adults

\begin{tabular}{|c|c|c|c|c|}
\hline \multirow{2}{*}{$\begin{array}{l}\text { Trans- } \\
\text { aminase } \\
\text { activity } \\
\text { micromoles/ } \\
\text { ml./hr. }\end{array}$} & \multicolumn{2}{|c|}{$\begin{array}{l}\text { Aspartate- } \\
\text { alpha-keto } \\
\text { glutarate }\end{array}$} & \multicolumn{2}{|c|}{$\begin{array}{l}\text { Alanine- } \\
\text { alpha-keto } \\
\text { glutarate }\end{array}$} \\
\hline & $\begin{array}{l}\text { No. of } \\
\text { samples }\end{array}$ & $\%$ & $\begin{array}{l}\text { No. of } \\
\text { samples }\end{array}$ & $\%$ \\
\hline $\begin{array}{l}0.20-0.39 \\
0.40-0.49 \\
0.50-0.59 \\
0.60-0.69 \\
0.70-0.79 \\
0.80-0.89 \\
0.90-0.99 \\
1.00-1.09 \\
1.36\end{array}$ & $\begin{array}{r}0 \\
7 \\
22 \\
24 \\
15 \\
5 \\
9 \\
5 \\
1\end{array}$ & $\begin{array}{r}0 \\
7.8 \\
25.0 \\
27.2 \\
17.1 \\
5.7 \\
10.2 \\
5.7 \\
1.1\end{array}$ & $\begin{array}{r}2 \\
11 \\
16 \\
5 \\
2 \\
1 \\
1 \\
1\end{array}$ & $\begin{array}{r}5.1 \\
28.2 \\
41.1 \\
12.5 \\
5.1 \\
2.5 \\
2.5 \\
2.5\end{array}$ \\
\hline $\begin{array}{l}\text { Total number } \\
\text { tested }\end{array}$ & 88 & 100 & 39 & 100 \\
\hline \multirow[t]{2}{*}{$\begin{array}{l}\text { Mean transaminase } \\
\text { activity } \\
\text { micromoles } / \text { ml. } / \mathrm{hr} \text {. }\end{array}$} & \multicolumn{2}{|c|}{$\begin{array}{l}\text { Aspartate- } \\
\text { alpha-keto } \\
\text { glutarate }\end{array}$} & \multicolumn{2}{|c|}{$0.622 \pm 0.191$ Std. } \\
\hline & \multicolumn{2}{|c|}{$\begin{array}{l}\text { Alanine- } \\
\text { alpha-keto } \\
\text { glutarate }\end{array}$} & \multicolumn{2}{|c|}{$0.525 \pm 0.146 \begin{array}{l}\text { Std. } \\
\text { deviation }\end{array}$} \\
\hline
\end{tabular}

the serum. No change in activity was noted in sera subjected to $56^{\circ} \mathrm{C}$. for 25 minutes. Sera heated to $100^{\circ} \mathrm{C}$. for ten minutes were found to have a decrease in activity to 10 per cent of the original transaminase activity.

No difference could be detected between transaminase activity in serum and in plasma from the same donors by using oxalate, citrate, or heparin as anticoagulants.

\section{Transaminase activity in the blood of normal humans}

The serum glutamic oxalacetic transaminase activity in 88 normal humans varied from 0.41 to 1.36 micromoles per $\mathrm{ml}$. per hour with a mean activity of $0.622 \pm 0.191$ standard deviation. Serum glutamic pyruvic transaminase activity in 39 samples was found to be between 0.21 and 1.01 micromoles per $\mathrm{ml}$. per $\mathrm{hr}$. with a mean value of $0.525 \pm 0.146$ (Table III). The glutamic oxalacetic transaminase activity found in hemolysates ranged from 5.0 to 8.7 micromoles per $\mathrm{ml}$. per hr. with a mean value of $6.86 \pm 0.78$ while the glutamic pyruvic transaminase in hemolysates varied from 1.6 to 3.3 micromoles per $\mathrm{ml}$. per $\mathrm{hr}$. with a mean value of $2.48 \pm 0.36$ (Table IV).

In each of 29 hemolysate samples, the ratio of 
TABLE IV

Distribution of transaminase activity in whole blood hemolysates of healthy adults

\begin{tabular}{|c|c|c|c|c|c|c|}
\hline \multicolumn{3}{|c|}{$\begin{array}{c}\text { Aspartate-alpha-keto } \\
\text { glutarate }\end{array}$} & & \multicolumn{3}{|c|}{$\begin{array}{l}\text { Alanine-alpha-keto } \\
\text { glutarate }\end{array}$} \\
\hline $\begin{array}{l}\text { Trans- } \\
\text { aminase } \\
\text { activity } \\
\text { micromoles/ } \\
\text { ml./hr. }\end{array}$ & $\begin{array}{c}\text { No. of } \\
\text { samples }\end{array}$ & $\%$ & & $\begin{array}{l}\text { Trans- } \\
\text { aminase } \\
\text { activity } \\
\text { micromoles/ } \\
\text { ml./hr. }\end{array}$ & $\begin{array}{c}\text { No. of } \\
\text { samples }\end{array}$ & $\%$ \\
\hline $\begin{array}{l}5.0-5.9 \\
6.0-6.9 \\
7.0-7.9 \\
8.0-8.9\end{array}$ & $\begin{array}{r}3 \\
12 \\
12 \\
2\end{array}$ & $\begin{array}{r}10.3 \\
41.4 \\
41.4 \\
6.9\end{array}$ & & $\begin{array}{l}1.5-1.9 \\
2.0-2.5 \\
2.5-3.0 \\
3.0-3.3\end{array}$ & $\begin{array}{r}3 \\
12 \\
11 \\
3\end{array}$ & $\begin{array}{l}10.3 \\
41.4 \\
38.0 \\
10.3\end{array}$ \\
\hline Total No. & 291 & 100.0 & & Total No. & 291 & 100.0 \\
\hline \multirow{2}{*}{\multicolumn{3}{|c|}{$\begin{array}{l}\text { Mean transaminase } \\
\text { activity } \\
\text { micromoles } / \text { ml. } / \mathrm{hr} \text {. }\end{array}$}} & $\begin{array}{l}\text { Aspartate- } \\
\text { alpha-keto } \\
\text { glutarate }\end{array}$ & \multicolumn{3}{|c|}{$\begin{array}{r}6.86 \pm 0.78 \text { Std. } \\
\text { deviation }\end{array}$} \\
\hline & & & $\begin{array}{l}\text { Alanine- } \\
\text { alpha-keto } \\
\text { glutarate }\end{array}$ & \multicolumn{3}{|c|}{$\begin{array}{r}2.48 \pm 0.36 \text { Std. } \\
\text { deviation }\end{array}$} \\
\hline
\end{tabular}

glutamic oxalacetic transaminase activity to glutamic pyruvic transaminase activity varied between 2.04 and 3.60 micromoles per $\mathrm{ml}$. per hr. with a mean value of $2.70 \pm 0.40$. In 39 determinations of serum transaminase activity, this ratio was found to be 0.725 to 1.67 micromoles per ml. per hr. with a mean of $1.15 \pm 0.23$. No consistent relationship was noted between individual serum and corresponding hemolysate transaminase activities.

In no instance was transaminase activity absent in the sera of the normal humans tested or in any of the sera of hospitalized patients with various disease states tested. Increased activity was found in the sera of one patient with lymphomatous disease, one with extensive rhabdomyosarcoma, two with acute leukemia, one with acute hepatitis, and two patients with arteriosclerotic heart disease and recent myocardial infarction. Serum glu-

TABLE V

Transaminase activity in blood of hospitalized patients in micromoles per ml. per hr.

\begin{tabular}{|c|c|c|c|c|}
\hline \multirow[b]{2}{*}{ Clinical diagnosis } & \multicolumn{2}{|c|}{$\begin{array}{c}\text { Serum transaminase } \\
\text { glutamic }\end{array}$} & \multicolumn{2}{|c|}{$\begin{array}{l}\text { Hemolysate transaminase } \\
\text { glutamic }\end{array}$} \\
\hline & Oxalacetic & Pyruvic & Oxalacetic & Pyruvic \\
\hline $\begin{array}{l}\text { Carcinoma of lung } \\
\text { Carcinoma of lung } \\
\text { Carcinoma of palate } \\
\text { Carcinoma of eyelid } \\
\text { Carcinoma of breast } \\
\text { Fibromyoma of uterus } \\
\text { Lymphoma } \\
\text { Lymphoma } \\
\text { Lymphoma } \\
\text { Lymphoma } \\
\text { Lymphoma } \\
\text { Lymphoma } \\
\text { Lymphoma } \\
\text { Lymphoma } \\
\text { Rhabdomyosarcoma } \\
\text { Rhabdomyosarcoma } \\
\text { Chronic pulmonary tuberculosis } \\
\text { Chronic pulmonary tuberculosis } \\
\text { Acute leukemia } \\
\text { Acute leukemia } \\
\text { Acute leukemia } \\
\text { Acute hepatitis } \\
\text { Diabetes mellitus } \\
\text { Portal cirrhosis } \\
\text { Portal cirrhosis } \\
\text { Generalized arteriosclerosis } \\
\text { Cerebral hemorrhage } \\
\text { Arteriosclerotic heart disease with CHF } \\
\text { ASHD with anginal syndrome } \\
\text { ASHD with myocardial infarction- } \\
\text { see Figure } 5\end{array}$ & $\begin{array}{l}0.54 \\
0.51 \\
0.89 \\
0.75 \\
0.80 \\
0.81 \\
0.46 \\
0.71 \\
0.52 \\
0.74 \\
1.06 \\
0.36 \\
0.47 \\
0.71 \\
1.70 \\
0.40 \\
0.92 \\
0.58 \\
1.28 \\
0.36 \\
1.72 \\
1.97 \\
0.46 \\
0.99 \\
0.49 \\
0.50 \\
0.85 \\
1.16 \\
0.95\end{array}$ & $\begin{array}{l}0.41 \\
0.38 \\
0.70 \\
0.47 \\
0.73 \\
0.59 \\
0.51 \\
0.47 \\
0.39 \\
0.53 \\
0.70 \\
0.32 \\
0.37 \\
0.48 \\
1.60 \\
0.35 \\
1.24 \\
0.44 \\
1.51 \\
0.55 \\
1.25 \\
1.75 \\
0.35 \\
1.28 \\
0.38 \\
0.63 \\
0.41 \\
0.81 \\
1.25\end{array}$ & $\begin{array}{c}8.86 \\
1.73 \\
6.25 \\
8.05 \\
\\
8.75 \\
11.3 \\
7.85 \\
6.45 \\
6.80 \\
6.35 \\
7.00 \\
\\
\\
9.13 \\
7.26 \\
7.20 \\
8.95 \\
5.26 \\
5.20 \\
7.95 \\
7.20 \\
8.46 \\
8.70 \\
3.10 \\
6.13 \\
9.40 \\
5.00 \\
8.65\end{array}$ & $\begin{array}{c}2.07 \\
2.54 \\
2.60 \\
1.80 \\
\\
2.73 \\
2.70 \\
1.56 \\
2.53 \\
1.66 \\
2.00 \\
1.60 \\
\\
\\
7.46 \\
2.00 \\
3.60 \\
1.60 \\
3.40 \\
1.60 \\
3.73 \\
10.4 \\
2.73 \\
3.50 \\
1.40 \\
3.26 \\
3.40 \\
2.20 \\
3.27\end{array}$ \\
\hline $\begin{array}{l}\text { Average normal value } \\
\text { Normal range* }\end{array}$ & $\begin{array}{c}0.62 \\
0.24-1.04\end{array}$ & $\begin{array}{c}0.52 \\
0.23-0.82\end{array}$ & $\begin{array}{c}6.86 \\
5.30-8.42\end{array}$ & $\stackrel{2.48}{1.76-3.20}$ \\
\hline
\end{tabular}

* Normal range represents the normal mean value plus or minus two standard deviations. 

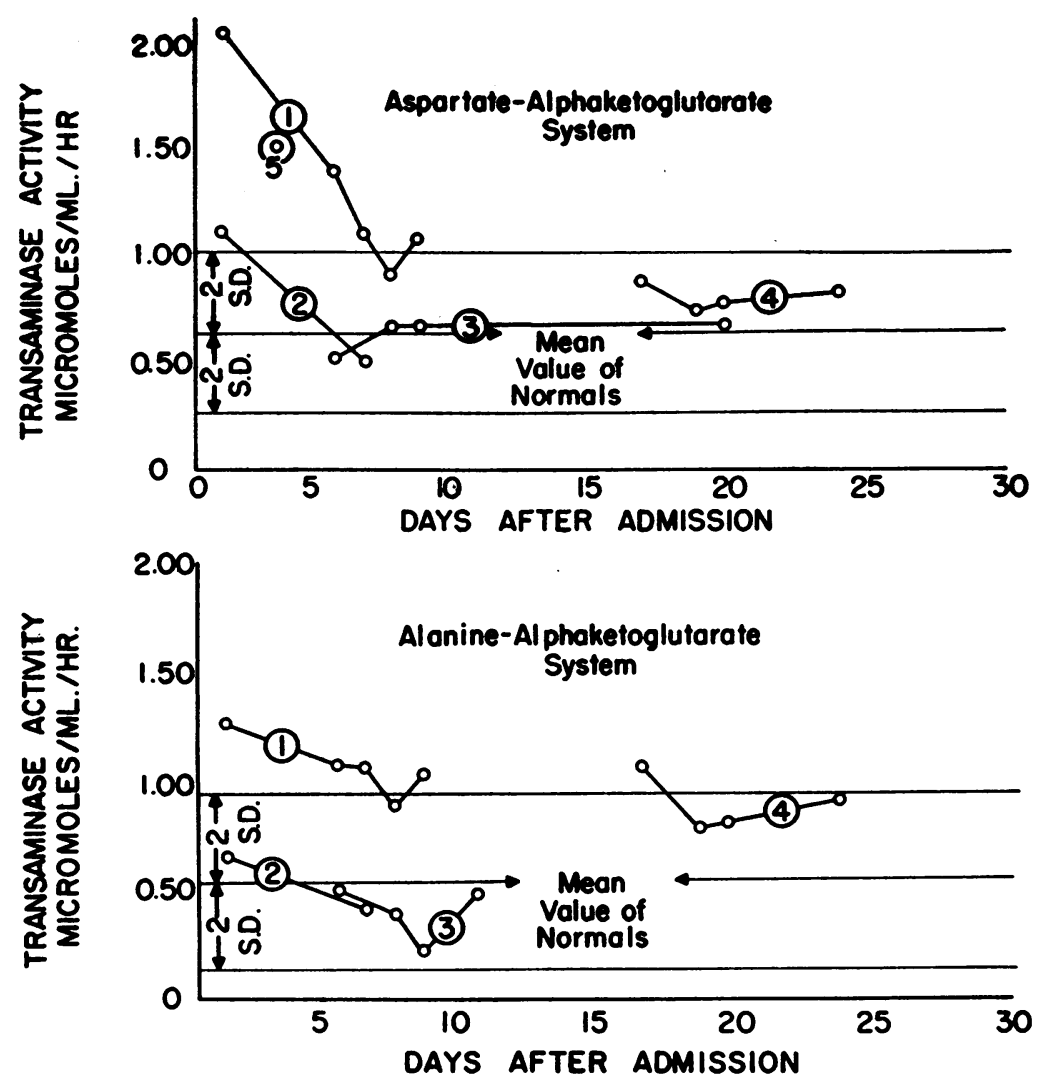

Fig. 4. Serum Transaminase Activity in Patients with admission Diagnosis of Myocardial Infarction

tamic oxalacetic transaminase activity and serum glutamic pyruvic transaminase activity was seen to vary together in most cases of marked departure from the normal range. Somewhat greater variation was found in the transaminase activity of the hemolysates from the same patients (Table V).

Figure 4 represents serial determinations of serum transaminase activity in five patients admitted to the hospital with the admitting diagnosis of acute myocardial infarction at various times after the onset of acute infarction. Of the five patients shown, the clinical picture subsequent to admission substantiated the diagnosis of transmural myocardial infarction in Nos. 1, 2, 4, and 5. Elevated values were found in patients Nos. 1 and 5, the only patients with acute infarctions studied during the first week after infarction. The finding of 2.02 units in patient No. 1 represents the highest value found in any of the samples tested and almost twice the value taken as the upper limit of normal.

\section{DISCUSSION}

The method of transaminase assay by quantitative paper chromatography of the glutamate produced was chosen because of its sensitivity and the simplicity of the equipment required. Other methods of measuring transamination reactions may be divided into two main types: Those utilizing either specific chemical or enzymatic decarboxylation of one of the products and subsequent manometric measurement of carbon dioxide evolved and those utilizing the high ultraviolet absorption of oxalacetate at wavelength 280 millimicra to follow the glutamic oxalacetic transaminase reaction by measuring a change in optical density as oxalacetate is produced or consumed. The high bicarbonate content of blood together with low transaminase activity makes a method depending on carbon dioxide evolution difficult to apply to serum. Low transaminase activity and high protein content together with the known instability of oxalacetate make the usual spectrophotometric assay difficult to apply to serum. 
The results demonstrated the enzymatic nature of the observed transamination and suggest that serum glutamic oxalacetic transaminase has similar chemical characteristics to transaminase derived from other sources. The failure of pyridoxal phosphate or boiled liver extract to increase the measured transaminase activity may be taken as evidence that the enzyme was fully activated in the serum samples tested. The difference in comparative amounts of the two transaminases in serum and hemolysates could represent a difference in the rates of diffusion of the two enzymes across the cellular membranes of the blood cells, or, as seems more likely, this difference could be taken as suggestive evidence for a source of the serum enzymes apart from the blood cells.

The sera of patients with acute myocardial infarction were thought worthy of particular attention because of the possibility that destruction of cardiac muscle, reported rich in transaminase activity, might result in a release of this enzyme into the blood stream and might thus increase the serum transaminase activity. The finding of increased serum transaminase activity in the two patients studied during the first week after infarction is compatible with such a possibility.

\section{SUM MARY}

1. The presence of glutamic oxalacetic and glutamic pyruvic transaminase activity in human serum, plasma, and whole blood hemolysates has been demonstrated. A method is presented for their measurement by estimating the rate of glutamate formation employing quantitative paper chromatography.

2. The chemical properties of the enzyme in serum, including the variation in activity with changes in concentration of enzyme, substrate, and hydrogen ion were found similar to those reported for transaminases in animal tissues. Freezing or lyophilizing the serum, or storing it at 0 to $5^{\circ} \mathrm{C}$. for periods up to two weeks resulted in no significant change in transaminase activity. Boiling destroyed the activity.

3. Glutamic oxalacetic and glutamic pyruvic transaminase activities were found to be approximately equal in normal human serum. Whole blood hemolysates were found to have ten times as much glutamic oxalacetic transaminase activity as serum. Glutamic oxalacetic transaminase was found to be approximately 2.7 times as active as glutamic pyruvic transaminase in hemolysates.

4. A survey of transaminase activity in the blood of hospitalized patients revealed departure from the normal range of activity in several disease states.

\section{ACKNOWLEDGMENT}

We wish to acknowledge gratefully the interest, advice and assistance of Drs. Aaron Bendich, Oscar Bodansky, Severo Ochoa, and Rulon Rawson.

\section{APPENDIX}

\section{A NOTE ON THE SPECTROPHOTOMETRIC ASSAY OF GLUTAMIC- OXALACETIC TRANSAMINASE IN HUMAN BLOOD SERUM}

\section{BY ARTHUR KARMEN}

\section{(Department of Pharmacology, New York University College of Medicine)}

A spectrophotometric method was devised in which the transamination reaction (Reaction 1) is coupled to the reduction of oxalacetate to malate by reduced diphosphopyridine nucleotide (DPNH), in the presence of an excess of purified malic dehydrogenase (Reaction 2). The oxidation of DPNH, and therefore the transamination reaction, is followed by measuring the de- crease in light absorption at wave length $340 \mathrm{~m} \mu$, at which the reduced pyridine nucleotides have an absorption peak.

(1) $\alpha$-Keto glutarate + aspartate $\leftrightarrows$ L-glutamate + oxalacetate

(2) Oxalacetate $+\mathrm{DPNH}+\mathrm{H}^{+} \rightleftarrows$ L-malate $+\mathrm{DPN}^{+}$ 


\section{METHODS}

Materials. Aspartic acid, alpha-keto glutaric acid and reduced diphosphopyridinenucleotide were obtained commercially. Purified malic dehydrogenase, prepared from pig heart muscle by the method of Straub (10), was tested and found free of detectable transaminase or glutamic dehydrogenase activity. ${ }^{1}$

Experimental procedure. From 0.1 to $1.0 \mathrm{ml}$. of serum, $1.0 \mathrm{ml}$. of $0.1 \mathrm{M}$ phosphate buffer, $\mathrm{pH} 7.4,0.5 \mathrm{ml}$. of $0.2 \mathrm{M}$ aspartate in buffer, $\mathrm{pH} 7.4,0.2 \mathrm{ml}$. of DPNH (1 mgm. per $\mathrm{ml}$.) and $0.1 \mathrm{ml}$. of a solution of purified malic dehydrogenase ( 50 micrograms of enzyme protein per $\mathrm{ml}$.) were mixed and brought to a final volume of $2.8 \mathrm{ml}$. in a cuvette having a $1.0 \mathrm{~cm}$. light path. The blank contained all reactants listed except DPNH. After 10 minutes,

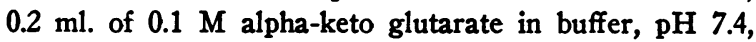
was added. The optical density at wavelength $340 \mathrm{~m} \mu$ was followed for five minutes, and the rate of decrease of

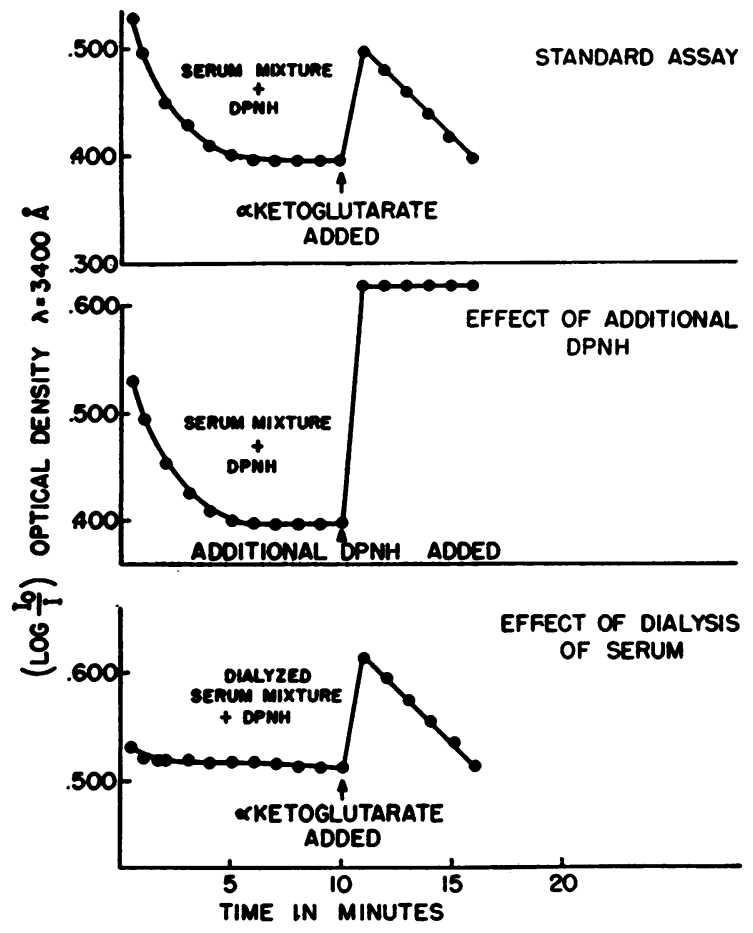

Fig. 5. Spectrophotometric Assay of Serum Transaminase

Top and bottom curves, all components except $\alpha$-keto glutarate present initially; $\alpha$-keto glutarate added at time indicated by arrows. Middle curve: all components present initially, additional DPNH at time indicated by arrow. DPNH added at zero time in all cases. The increase in optical density when $\alpha$-keto glutarate is added is due to the absorption of light by $\alpha$-keto glutarate at this wavelength.

1 I am indebted to Dr. Martin Schwartz for this preparation.

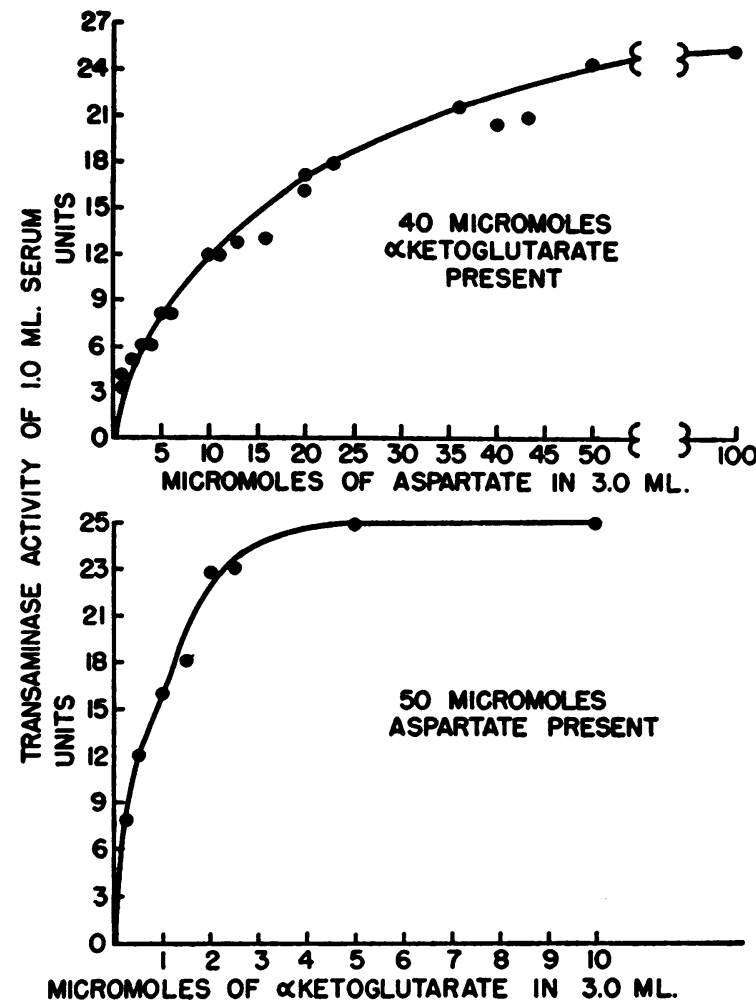

Fig. 6. Serum Transaminase Activity as a Function of Substrate Concentration

optical density taken as the measure of the transaminase activity of the serum. The reaction was followed in a Beckman model DU spectrophotometer at room temperature. The activity is expressed as units per $\mathrm{ml}$. of serum per minute. One unit equals a decrease in optical density of 0.001 under the conditions described,

Comments on procedure. When DPNH is added to serum without addition of substrates the optical density of the mixture decreases for six to seven minutes, indicating the oxidation of a finite quantity of DPNH. After this reaction has stopped, completion of the transamination system results in a steady decrease in optical density which is taken as a measure of the transaminase activity of the serum (Figure 5, top curve).

The rate or amount of DPNH oxidation by serum alone is not changed by the addition of malic dehydrogenase and either aspartate or alpha-keto glutarate. The amount oxidized is not appreciably affected by adding more DPNH (Figure 5, middle curve). Addition of $0.2 \mathrm{ml}$. of a solution of potassium pyruvate $(4 \mathrm{mgm}$. per ml.), after this reaction has stopped, results in complete oxidation of the DPNH present at a measurable rate, demonstrating the presence of lactic dehydrogenase in serum. Dialysis of the serum against $0.1 \mathrm{M}$ phosphate buffer reduces the amount of DPNH oxidized without changing the measurable transaminase activity of the serum (cf. Figure 5, top and bottom curves). 
It is, therefore, suggested that the oxidation of DPNH by serum alone depends on the presence of pyruvate and lactic dehydrogenase in serum. The reaction stops when all the pyruvate is enzymatically reduced to lactate by DPNH.

Omitting malic dehydrogenase from otherwise complete transamination reaction mixtures resulted in a variable decrease in the observed rate of DPNH oxidation. That the reaction was still measurable was taken as suggestive evidence either for the presence of malic dehydrogenase in serum or for the decarboxylation of oxalacetate to pyruvate and subsequent DPNH oxidation by lactic dehydrogenase. Addition of more malic dehydrogenase to any serum transaminase assay resulted in no further increase in the measured rate of reaction, indicating that the enzyme was present in excess in the assay mixture.

\section{RESULTS}

Study of the variation of serum transaminase activity with substrate concentration indicated that maximal activity was obtained when the three $\mathrm{ml}$. reaction mixture contained more than 50 micromoles of aspartate and 5 micromoles of alpha-keto glutarate (Figure 6). One hundred micromoles of aspartate and 20 micromoles of alpha-keto glutarate were used in subsequent determinations.

Proportionality of the observed rate of reaction to the amount of serum present was observed over a wide range of serum transaminase activities (Figure 7).

Transaminase activity was measured in the sera of 50 normal humans in addition to those deter-

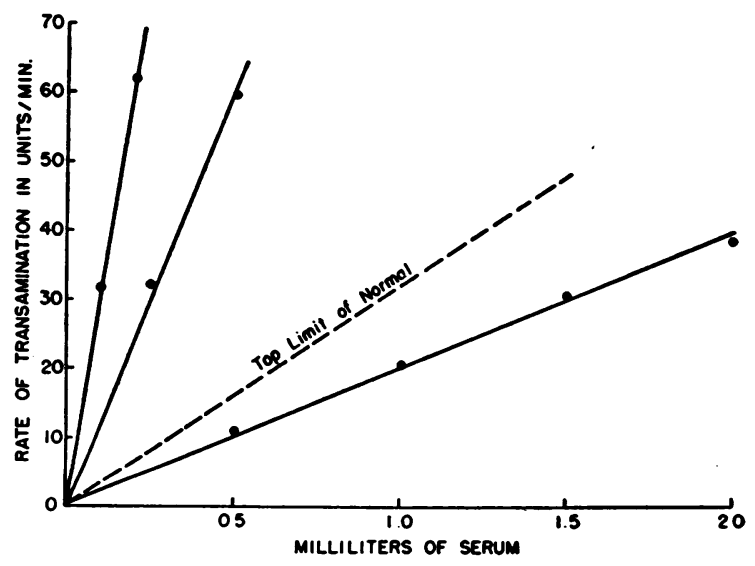

Fig. 7. Transaminase activity as a Function of Serum Concentration

Three different serum samples. mined by the chromatographic assay method. The values found ranged from a low of nine to a high of thirty-two units per ml. per minute with a mean value of 19.6. Conversion of these units to micromoles per $\mathrm{ml}$. per hour, using the extinction coefficient for DPNH determined by Horecker and Kornberg (11) gives a mean value of 0.57 , which falls within the range of 0.24 to 1.04 micromoles per ml. per hour found by the quantitative paper chromatographic assay.

\section{ACKNOWLEDGMENT}

The author wishes to express his appreciation to Dr. Severo Ochoa for invaluable help in performing this work.

\section{REFERENCES}

1. Awapara, J., Effect of protein depletion on the transaminating activities of some rat organs. J. Biol. Chem., 1953, 200, 537.

2. Cohen, P. P., Hekhuis, G. L., and Sober, E. K., Transamination in liver from rats fed butter yellow. Cancer Research, 1942, 2, 405.

3. Braunstein, A. E., Transamination and the integrative functions of the dicarboxylic acids in nitrogen metabolism. Adv. Protein Chem., 1947, 3, 11.

4. Awapara, J., and Seale, B., Distribution of transaminases in rat organs. J. Biol. Chem., 1952, 194, 497.

5. Brush, M. K., Boutwell, R. K., Barton, A. D., and Heidelberger, C., Destruction of amino acids during filter paper chromatography. Science, 1951, $113,4$.

6. Troll, W., and Cannan, R. K., A modified photometric ninhydrin method for the analysis of amino and imino acids. J. Biol. Chem., 1953, 200, 803.

7. O'Kane, D., and Gunsalus, I. C., The resolution and purification of glutamic-aspartic transaminase. J. Biol. Chem., 1947, 170, 425.

8. Nisonoff, A., Henry, S. S., and Barnes, F. W., Jr., Mechanisms in enzymatic transamination: Variables in the spectrophotometric estimation of glutamic-aspartate kinetics. J. Biol. Chem., 1952, 199, 699.

9. Cohen, P. P., Kinetics of transaminase activity. J. Biol. Chem., 1940, 136, 585.

10. Straub, F. B., Reinigung der Äpfelsäuredehydrase und die Bedeutung der Zellstruktur in der Äpfelsäuredehydrierung. Ztschr. f. physiol. Chem., 1942, 275, 63.

11. Horecker, B. L., and Kornberg, A., The extinction coefficients of the reduced band of pyridine nucleotides. J. Biol. Chem., 1948, 175, 385. 